\author{
Karadeniz Uluslararası Bilimsel Dergi \\ Volume: 49, Spring-2021, p. (165-178) \\ ISSN: 1308-6200 DOI Number: https://doi.org/10.17498/kdeniz.879183 \\ Research Article \\ Received: February 12, 2021 | Accepted: March 15, 2021 \\ This article was checked by turnitin.
}

\title{
HALAÇ SARAYINDA BİR KÖLE: MELİK KÂFÛR HEZÂRDÎNÂRî ${ }^{1}$
}

\author{
A SLAVE IN THE HALAÇ PALACE: MELİK KÂFÛR HEZÂRDÎNÂRî
}

РАБ ИМЕНЕМ МЕЛИК КАФУР ХЕЗАДИНАРИ ВО ДВОРЦЕ ХАЛАЧ

Metin BİLAL *

Öz

Delhi merkezli kurulan Müslüman Türk devletlerinden biri de Halaç ya da Kalaç Sultanlı̆̆ı'dır. Sultan Celâleddin Firuz Şah ile başlayan Delhi Halaçlarının hâkimiyeti Alâeddin Muhammed Şah ile zirveye çıkmıştı. Onun askeri kabiliyeti ve zekiliği neticesinde bir yandan Moğol baskınları durdurulurken diğer yanda da racaların birçoğuna boyun eğdirilmişti. Böylece Hint yarımadası büyük oranda Halaçların hâkimiyeti altına girmişti. Bunda şüphesiz Melik Kâfûr'un etkisi büyüktü. Alâeddin Muhammed Şah'ın saltanatı yaklaşık 20 yıl sürmüştü. Ancak saltanatının son zamanlarında Melik Kâfûr'un etkisinde kalmış ve çocuk yaşta şehzade Ömer'i varisi yapmıştı. Bu durum da Melik Kâfûr'u Halaç tahtını ele geçirmek için daha çok iştahlandırmıştı. Sultan Alâeddin'in ölümü üzerine Kâfûr, Şehzade Ömer'i tahta çıkarmıştı. Kendisine karşı oluşabilecek mukavemeti ortadan kaldırmak için de şehzadelerin gözlerine mil çektirmişti. Onun bu düşmanlığından sadece Mubarek Han kurtulabilmişti. Melik Kâfûr'un öldürülmesinden bir süre sonra Mubarek Han tahtı ele geçirmişti. Ancak onun da salatanı uzun sürmemiş ve tahta Hüsrev Han geçmişti. Nihayetinde Delhi Halaç Sultanlığı 1320 yllına gelindiğinde yerini Tuğlukşahlar Devleti'ne bırakarak tarih sahnesinden çekilmişti.

$\mathrm{Bu}$ makale de köle iken satın alınan Hint asıllı Kâfûr'un Halaç sarayına getirilmesiyle başlayan serüveni hakkında bilgi verilmiştir. Onun ordu komutanı olarak çıtığı Deogir, Varangal, Dvarasamudra ve Ma‘ber seferleriyle ilgili etraflıca bilgi verilmeye çalışılmıştır. Ayrıca Halaç yönetimini ele geçirmek için çevirdiği entrikalar ve bunun sonucunda da öldürülmesi hakkında da bilgi verilmiştir. Son olarak Melik Kâfûr'un türbesiyle ilgili bilgi verilmiştir.

Anahtar Kelimeler: Halaç Sultanlığı, Alâeddin Muhammed Şah, Melik Kâfûr, Deogir, Varangal

\footnotetext{
*ORCID:0000-0003-3150-8272,Dr, Atatürk Ü. Tarih Bölümü, metinbilal61@ @hotmail.com ${ }^{1}$ İbn Battûta Kâfûr'un bin tengeye yani binbeşyüz Mağrip altınına satın alındığından bahsetmektedir. Ayrıca bundan dolayı Kâfûr'un "Elfi”" (binlik) lakabıyla anıldığını belirtmektedir. Ancak seyyahın verdiği bu bilgi döneme 1 şı tutan diğer kaynaklarda geçmemektedir (İbn Battûta, 2000:632).
} 


\section{Halaç Sarayında Bir Köle: Melik Kâfûr Hezârdînârî}

\section{ABSTRACT}

One of the Muslim Turkish states established in Delhi is the Halaç or Kalaç Sultanate. The rule of Delhi Apostles, which started with Sultan Celaleddin Firuz Shah, reached its peak with Alaeddin Muhammed Shah.As a result of his military ability and intelligence, Mongol raids were stopped on the one hand and many of the rajas were subjugated on the other. Thus, the Indian peninsula was largely dominated by the Kalaç.Undoubtedly, Melik Kafur had a great influence on this. The sultanate of Alaeddin Muhammed Shah lasted nearly 20 years.However, in the last days of his reign, he was under the influence of Melik Kafur and made the prince Ömer as his heir at a young age. This situation made Melik Kafur more appetite to seize the Kalaç throne.Upon the death of Sultan Alaeddin, Kafur enthroned Prince Ömer. In order to eliminate the resistance that could be formed against him, he had taken shaft in the eyes of princes. Only Mubarek Khan was able to escape from his hostility. A while after the murder of Melik Kafur, Mubarek Khan had taken the throne. However, his reign did not last long and Hüsrev Khan had passed the throne.Ultimately, the Delhi Halaç Sultanate left the stage of history, leaving its place to Tuğlukşahs in 1320. In this article, information about the adventure of Kafur, who was bought while he was a slave and was brought to Halaç Palaceis given.It was tried to give detailed information about the Deogir, Varangal, Dvarasamudra and Ma'ber campaigns, which he started as the army commander. In addition, information was given about the intrigues he made to take over Halac's administration and his death as a result. Finally, information about the tomb of Melik Kafur was given.

Keywords: Halaç Sultanate, Alâeddin Muhammed Shah, Melik Kâfûr, Deogir, Varangal

\section{АННОТАЦИЯ}

Одним из турецких мусульманских государств, основанных в Дели, является салтанат Халач или Калач. Правление Дели Халаджов, начавшееся при султане Джалаледдине Фируз-шахе, достигло своего пика при Алаеддине Мухаммедшахе.Благодаря его военным способностям и интеллекту, с одной стороны были остановлены набеги монголов, а с другой, были побеждены многие раджи.Таким образом, на Индийском полуострове в значительной степени доминировали Халачы. Несомненно, большое влияние на это оказал Мелик Кафур. Правление Алаеддина Мухаммеда Шаха длилось около 20 лет. Однако в последние дни своего правления он находился под влиянием Мелика Кафура и в юном возрасте сделал принца Омера своим наследником.Эта ситуация усилила желание Мелика Кафура захватить трон Халача. После смерти султана Алаэддина Кафур возвёл на престол принца Омера. Чтобы устранить сопротивление, которое могло было быть предпринято против него, онослепил глаза у принцовокалённым валом.Только Мубарек-хан смог спастись от его враждебности. Через некоторое время после убийства Мелика Кафура трон захватил Мубарек-хан. Однако его правление длилось недолго и Хусрев Хан был возведен на престол.В конце концов, Дели Халач сошёл с исторической сцены, уступив свое место Туглукшахаму в 1320 году. В нижеследующей статье даётся информация о приключении Кафура с момента, когда он был куплен при нахождении в рабстве и когда его привезли во дворец Халач.Была предпринята попытка дать подробную информацию о военных походах в Деогир, Варангал, Дварасамудра и Мабер, которые Кафурначал как командующий армией.Кроме того, была предоставлена информация об интригах, которые он устроил с целью захваты власти в Халаче, что и окончательно привело его к смерти.Отдельно даётся информация о могиле Мелика Кафура. 
Ключевые слова: Салтанат Халач, Алаеддин Мухаммед Шах, Мелик Кафур, Деогир, Варангал.

\section{Giriş}

Celâleddin Firuz Şah Balabanların hâkimiyetine son vererek 13 Haziran 1290 tarihinde tahta çıkmıştı. Böylece Delhi Halaç Sultanlığı dönemi başlamıştı (Köprülü,1966:140-1;Köprülü,1978: 279). Kara valisi Melik Alâeddin onun damadı ve yeğeniydi. Alâeddin bir suikast sonucu amcası Celâleddin'i ortadan kaldırmıştı. Onun yerine tahta geçen Rukneddin İbrahim'i bertaraf eden Melik Alâeddin 21 Aralık 1296 tarihinde Delhi'de hükümdarlığını ilan etmişti (Halaçoğlu, 1989: 330). Böylece Halaç tahtında en uzun süre kalan ve en büyük hükümdarın saltanatı başlamıştı. Alâeddin Muhammed Şah bölgede kısa sürede nüfuzunu tesis ettikten sonra Hint sınırlarını tehdit eden Moğollara karşı askeri tedbirler almışt1. Askeri seferleri neticesinde kuzeyde Multan, Lahor, Delhi güneyde Dvarasamudra, Mab'er doğuda Lekhenevti, Sunargon batıda Thatta ve Gücerat'a kadar alanları hâkimiyeti altına almıştı (Köprülü, 1978: 279-80; Kafesoğlu, 1976: 323). Alâeddin Muhammed Şah başarılı bir şekilde devleti yaklaşık 20 yıl yönettikten sonra 4 Ocak 1316 tarihinde vefat etmişti (Singh, 2005: 117).

\section{Kâfûr Hezârdînârî}

Hint asıllı hadım köle olan Kâfûr yakışıklı ve oldukça genç yaştaydı. Gerçek ismi bilinmemekle birlikte daha çok Kâfûr lakabıyla anılmaktaydı (Haig, 1928: 100). Kâfûr, Nusret Han tarafından 1299 tarihinde Kambay' da Müslüman bir tâcirden satın alınmıştı. Nusret Han,Kâfûr için tâcire bin dinar ödemişti. Bundan dolayı Kâfûr "Hezârdînârî"? olarak anılmıştı (Berenî, 2015: 154; Nizâmeddin Ahmed, 1927: 157; Firişte, 1829: 184; Konukçu, 1976: 795; Lal, 1966: 161). Ayrıca Kâfûr'a "Tacedddin" ve “İzzed-Devle"gibi unvanlar verilmişti. Bu unvanları Halaç sarayına geldikten sonra almıştı. Kâfûr'un ailesine ve çocukluğuna dair kaynaklarda bilgi bulunmamaktadır.İsami'den aktaran Digby onun orijinde Marhatta (Maratha)'lı olduğunu belirtmektedir (Digby, 1978: 419).Enver Konukçu ise onun Gücerat yerlilerinden olduğunu vurgulamaktadır (Konukçu, 1987: 355).

Kâfûr satın alındıktan sonra Delhi'ye getirilerek Sultan Alâeddin Muhammed Halaci'ye takdim edilmişti. Kâfûr Sultan Alâeddin'i etkilemeyi başarmış ve zamanla en gözde adımı olmuştu. Bundan dolayı Sultan Alâeddin onu Nâ'ib-i Melik'liğge kadar yükseltmişti (Berenî, 2015: 154; Nizâmeddin Ahmed, 1927:157; Saksena, 1970: 335; Kortel, 1994: 74). Dönemin kaynaklar1 Kâfûr'un saraya alınmasından sonra bir müddet onunla ilgili bilgi vermeyi durdurmuşlardi. Ta ki 1308 yılında Çağataylılarla mücadelesine kadar (Dihlevî, 1970: 73; Firişte, 1829: 208; Berenî, 2015: 199). Kaynakların bir süre Kâfûr hakkında bilgi vermemesi onun Halaç sarayında geçirdiği hayatı ve Nâ'ib-i Melik Bârbeğ'liğe kadar uzanan serüvenin aydınlatılmasını kısıtlamıştı. 


\section{Halaç Sarayında Bir Köle: Melik Kâfûr Hezârdînârî}

Melik Kâfûr, Sultan Alâeddin'in Güney Hindistan racalıklarını hâkimiyet altına alma politikasında büyük rol oynamıştı. Bu doğrultuda Deogir, Varangal, Dvarsamudra ve Ma'ber üzerine sefere çıkarak bölgelerin racalarını itaati atına almıştı. Kâfûr, sultanın Güney Hindistan politikasını başarılı bir şekilde gerçekleştirdiği gibi bu seferler sırasında ele geçirdiği birçok altın ve değerli eşyayı Halaç hazinesine kazandırmıştı. Bunların dışında racalardan yıllık vergi karşıllı̆ında elde ettiği birçok değerli fili de sultanın hizmetine sunmuştu (Berenî, 2015: 199-204; Konukçu, 1977: 175-84).

Sultan Alâeddin Muhammed Şâh 23 Haziran 1310 tarihinde Caputra-i Naşiri'de Varangal seferi galibi Melik Kâfûr'u karşılayarak gösterdiği başarıdan ötürü ona "İzzed-devle " unvanı vermişti (Cöhce, 2008: 83; Konukçu, 1977:181; Lal 1950: 201). Melik Nâ‘ib Kâfûr çıktığı seferlerden büyük başarı elde etmişti. Onun bu başarısı Sultan Alâeddin nezdinde saygınlığını ve etkisini artırmıştı. Aynı zamanda Melik Kâfûr da şeytansı politikaları sayesinde sultan üzerinde mütemadî artan bir nüfuz kurmuştu. Melik Kâfûr, sultan üzerindeki nüfuzunu kullanarak bütün gücü ele geçirmek istemişti. Bu gaye doğrultusunda sultanın ailesi arasına nifak tohumları ekmişti. Böylece Sultan Alâeddin'den sonra tahta geçecek şehzadeyi kendi isteği doğrultusunda tayin ettirmişti (Köprülü, 1978: 281).

Melik Nâ‘ib Kâfûr, Sultan Alâeddin'in ölümünden sonra 6 yaşındaki Şehzade Ömer Han'ı tahta çıkarmıştı. Bu hamlesiyle Halaç tahtını tamamen kendi hâkimiyetine almaya çalışmıştı. Kâfûr Halaç tahtına çıkmak için bütün entrikaları sergilerken tertiplenen bir suikast sonucu öldürülmüştü (Berenî, 2015: 299-302; Nizâmeddin Ahmed,1927: 190-1; Firişte,1829: 219-20).

\section{Melik Kâfûr Hezârdînârî’nin Askeri Seferleri}

Nâ‘ib Kâfûr, Sultan Alâeddin tarafindan birçok seferde ordu komutanı olarak vazifelendirilmişti. Bu doğrultuda Deogir,Varangal, Dvarsamudra, Ma'ber ve üçüncü Deogir seferlerine çıkmıştı. Kâfûr bu seferlerden muzaffer bir ordu komutanı olarak Delhi'ye dönmeyi başarmıştı.

\subsection{Moğollara Karşı Mücadelesi}

Moğollar Kebek komutasındaki orduyu Halaçlar üzerine göndermişti. Moğol birlikleri önce Sind'e ardından da Samana ve Kuhram'a ulaşmışlardı. Akabinde yönlerini Nagaur şehrine çevirmişlerdi (Dihlevî, 1970: 73; Saksena, 1970: 393-4). Sultan Alâeddin Muhammed Şah, Melik Kâfûr komutasındaki Halaç ordusunu onlar üzerine sevk etmişti (Dihlevî, 1970: 73; Saksena, 1970: 394).Kâfûr, Moğol kuvvetlerine karşı cesurca mücadele etmiş ve Kebek'in kuvvetlerini bozguna uğratmıştı. Esir aldığı Kebek ve askerlerini Delhi'ye getirmişti (Singh, 2005: 107) .

\subsection{Deogir Seferi}

Sultan Celaleddin Firuz Şah döneminde Melik Alâeddin Muhammed Deogir üzerine sefere çıkarak burasını zapt etmişti. Nihayetinde Deogir racası Ram Deva Halaçlara tabi olarak yıllık vergi vermekteydi. Ancak Celaleddin'in suikast 
sonucunda öldürülmesini ve tahta Alâeddin'in geçmesini kabul etmemişti. Bundan dolayı Sultan Alâeddin'in saltanatını tanımayarak Halaçlara ödediği yıllık vergiyi ödememekteydi (Konukçu, 1977: 175; Berenî, 2015: 199; Kortel, 1998: 765; Srivastava, 1966: 166). Ram Chadra Deva'nın bu tutumu üzerine Alâeddin Muhammed Şah 1308 y1lında 30 bin kişiden oluşan orduyu onun üzerine göndermişti. Kâfûr'un komutasındaki orduya Nâ'ib-i Ârız-1 Memâlik Hâce Hâcî'nin yanı sıra Mâlva valisi Aynülmülk Multanî ve Gücerat valisi Alp Han da maiyetleriyle katılmışlardı (Kortel, 1998: 765; Nizâmeddin Ahmed, 1927:181; Firişte, 1829:208).

Melik Kâfûr Hezârdînârî hızlıca ilerleyerek Deogir'e varmış ve Şehri kalesiyle kuşatma altına almıştı. Ram Chadra Deva Halaç ordusu karşısında çok fazla tutunamayacağını anlayarak aman dilemişti. Böylece Ram Chadra Deva, çocukları, kadınları ve bütün hazinesi ele geçirilmişti. Ayrıca racanın 17 fili de tutsak edilmişti (Nizâmeddin Ahmed, 1927: 181; Berenî, 2015:199-200; Merçil, 206: 328). Akabinde Deogir'in ele geçirildiğini müjdeleyen fetihname Delhi'ye gönderilmişti. Fetihnamenin camilerde okunmasından sonra davullar çalınarak kutlama yapılmıştı (Berenî, 2015: 200).

Melik Nâ‘ib Kâfûr ele geçirdiği esirler ve hazineyle Delhi’ye dönmüştü. Ram Chadra ve ailesi altı ay Delhi'de kalmış ve bu süre zarfında da sultandan iyi muamele görmüşlerdi. Sultan Alâeddin, racaya çetr ve "ray-ı rayan" (racaların racası) unvanı vermişti. Deogir'in yönetimine getirerek bir lek altın (100 bin tenge) ihsanda bulunmuştu. Raca Ram Chadra Deva bu gelişmelerden sonra mahiyetiyle Deogir'e dönmüş ve Halaçlara bağlılığını sürdürmüştü (Konukçu, 1977: 176-7; Kortel, 1998: 766; Srivastava, 1966: 166).

\subsection{Varangal Seferi}

Deogir seferi üzerinden bir yıl geçmişti ki Melik Kâfûr Varangal seferiyle vazifelendirilmişti. Sultan Alâeddin Muhammed Şah 31 Ekim 1309 tarihinde Kâfûr komutasındaki orduyu Telingana'nın başkenti Varangal üzerine sevk etmişti (Nizâmeddin Ahmed, 1927: 181-2; Berenî, 2015: 200; Firişte, 1829: 212; Dihlevî, 1970:78; Kortel, 2015: 4). Sultan, Melik Nâ'ib'e Raca Pratap Rudra Deva eskiden olduğu gibi mücevher, fil, at ve yıllık vergi vermeyi taahhüt edecek olursa onunla anlaşması yönünde hüküm vermişti. Melik Kâfûr ve Hâce Hâcî Delhi'den hareket ederek Rabri ${ }^{3}$ Kasabasına gelmişlerdi. Burası Melik Kâfûr'un iktâsı dâhilinde bir kasabayd. Melik, Halaç ordusunu burada toplayarak Deogir istikametinde ilerlemişti. Bir müddet sonra Çenderi'ye ulaşılmıştı. Bu esnada melik ve emirleri gelerek Kâfûr'un birliklerine katılmışlardı (Berenî, 2015: 201; Nizâmeddin Ahmed, 1927: 182). Halaç ordusu buradan ilerleyerek Deogir'e ulaşmıştı. Deogir yöneticisi Raca Ram Deva Halaç ordusunu karşlayarak meliklere, emirlere ve ordu komutanlarına hediyeler vererek ihsanda bulunmuştu. Ordunun ihtiyaçlarının temin edilmesi için gerekli özveriyi göstererek bölge esnafını da bu doğrultuda seferber

\footnotetext{
${ }^{3}$ Kortel, Rabari (Revârî) olduğunu belirtmektedir (Kortel, 1998:768).
} 


\section{Halaç Sarayında Bir Köle: Melik Kâfûr Hezârdînârî}

etmişti. Böylece askerler rahatlıkla bütün ihtiyaçlarını temin etmişlerdi (Nizâmeddin Ahmed, 1927: 182; Kortel, 1998: 768; Berenî, 2015: 201).

Kâfûr ve maiyetindekiler Deogir'de birkaç gün konakladıktan sonra Varangal istikametinde ilerleyişini sürdürmüştü. Raca Deva Varangal sınırına kadar ordunun güzergâhı üzerindeki köylere adamlar göndermiş ve ihtiyaç duyulması halinde ordunun gereksinimlerinin karşılanmasını buyurmuştu. Kendisi de birkaç menzil Kâfûr'a eşlik etmiş ve akabinde Deogir'e geri dönmüştü (Berenî, 2015: 201; Kortel, 1998:768-9). Halaç ordusu güzergâhı üzerindeki köy ve kasabaları yağmalayarak Telingana'ya varmıştı. Akabinde Varangal Kalesi muhasara altına alınmıştı. Varangal yöneticisi Prapat Rudra Deva ise Halaç ordusunun geldiğini haber alınca maiyetiyle iç kaleye çekilmişti (Nizâmeddin Ahmed, 1927: 182; Berenî, 2015: 201; Firişte, 1829: 212). İki taraf üstünlük sağlamak için tahrip gücü yüksek mancınıklarla birbirlerine saldırmışlardı. Kâfûr'un kuvvetleri üstünlük göstererek dış kaleyi ele geçirmişlerdi. Akabinde tamamen taştan yapılmış iç kaleyi muhasara altına almışlardı (Kortel, 1998: 771). Yaşanan bu gelişmeler karşısında çaresiz kalan Rudra Deva, Melik Kâfûr'a elçi göndererek aman dilemişti. Melik Kâfûr, Sultan Alâeddin Muhammed Şah'ın emri doğrultusunda Prapat Rudra Deva ile sulh yapmıştı. Anlaşmanın maddelerine göre:

$\checkmark$ Terbiye edilmiş 100 fil

$\checkmark$ Telingana'nın iyi cins atlarından 7 bin at

$\checkmark$ Hazinede bulunan değerli mücevherlerin bir kısmı

$\checkmark$ Prapat Rudra Deva adına darp edilmiş altın ve gümüş para

$\checkmark$ Belirlenecek yıllık vergiyi düzenli olarak Delhi’ye göndermek.

Raca bütün şartları kabul etmiş ve anlaşma sağlanmıştı. Akabinde 19 Mart 1310 tarihinde Melik Kâfûr ve ordusu Delhi'ye dönmek için Varangal'dan ayrılmıştı (Berenî, 2015: 202; Cöhce, 2002: 712; Konukçu, 1977: 179). Melik Kâfûr Varangal'ın ele geçirildiğini Sultan Alâeddin'e müjdelemek için Fetihnameyi Delhi'ye göndermişti. Fetihname Cuma günü camilerde okunduktan sonra davullar çalınmış ve kutlamalar yapılmıştı (Berenî, 2015: 202). Melik Kâfûr 23 Haziran 1310 tarihinde Delhi'ye ulaşmıştı. Sultan Alâeddin Muhammed Şah Kâfûr'u karşılamak için Bedâun Kapısı yakınlarındaki Çatvara-i Nâsirî'ye gelmişti. Burada gerçekleştirilen büyük bir törenle Melik Kâfûr Varangal seferinden elde ettiği ganimetleri sultana takdim etmişti (Nizâmeddin Ahmed, 1927: 182; Firişte, 1829: 213; Kortel, 1998: 771).

\subsection{Dvarasamudra ve $\mathrm{Ma}^{6}$ ber Seferleri}

Melik Kâfûr Varangal seferi sırasında Ma'ber belgesinde 500 büyük filin olduğunu haber almıştı. Sultan Alâeddin ile görüşerek onları ele geçirme düşüncesinde olduğunu bildirmişti (Lal, 1950: 201; Kortel, 1998: 772). Bunun üzerine Sultan Alâeddin Halaç ordusunu Melik Kâfûr komutasında $1310^{4}$ yılının

\footnotetext{
${ }^{4}$ Konukçu 20 Kasım 1310 tarihini verirken Kortel de 18 Kasım 1310 tarihini vermektedir (Konukçu, 1977:181; Kortel, 1998: 772).
} 
sonuna doğru Dvarasamudra ve Ma ber üzerine göndermişti (Berenî, 2015: 203; Nizâmeddin Ahmed, 1927: 182; Firişte, 1829: 213). Melik Kâfûr ve Hâce Hacî sefer için Delhi' den hareket etmişlerdi. Halaç ordusu Cumne Nehri'ni takip ederek güney istikametinde ilerlemişti. Bârbeğ Melik Kâfûr ve maiyeti Cumne Nehri kıyısında bulunan Tankal'a ulaşmışlardı. Sultanın ordusu burada bir süre konakladıktan sonra birçok nehri aşmış ve 4 Şubat 1311 tarihinde Deogir'e ulaşmıştı (Lal, 1950: 202). Melik Kâfûr burada birkaç gün konaklayarak sefer için hazırlık yapmıştı. Halaç ordusu 7 şubatta Deogir'den ayrılarak Sînî, Godavari ve Bhinûr ırmaklarını geçmişlerdi. Akabinde Harâbâbâd'a oradan da Bandrî̀ye ulaşmıştı. Kâfûr, Sundara Pandya ve Vîra Bîr Pandya'nın birbirlerine savaş açtıkları haberini almıştı. Bu durumdan istifade etmek isteyen Dvarasamudra Racası Vîra Ballala Deva III savunmasız yakalayarak onları yağmalamak için harekete geçmiş ve Kâfûr'un geldiğini haber alınca da geri dönmüştü (Kortel, 1998: 773; Lal, 1950: 202-4).

Melik Kâfûr Dvarasamudra önlerine ulaşmış ve bütün hazırlıkları yaptıktan sonra 24 Şubat 1311 tarihinde bölgeyi muhasara altına almıştı. Halaç ordusu karşısında çok fazla direnemeyen Raca Vîra Ballala Deva teslim olmuştu. Sultan Alâeddin'e bağlı kalacağına dair teminat veren Raca Vîra Ballala Deva'nın hayatı bağışlanmıştı (Konukçu, 1977: 182). Böylece Dravasamudra fethedilerek Deva'nın hazinesi ve 36 fiil ele geçirilmişti. Melik Kâfûr fetihnameyi Delhi'ye gönderdikten sonra Ma'ber için harekete geçmişti (Berenî, 2015: 204). Halaç ordusu 10 Mart 1311 tarihinde harekete geçmiş ve ilerlemesi oldukça güç yolları aşarak Mâ‘ber sınırına ulaşmıştı. Kâfûr, Tarmali ve Toppur'u geçerek Mardi şehrine ulaşmıştı. Akabinde Kanobari irmağı kıyısndan harekete geçilerek Birdhûl'e gelinmişti. Mâ'ber racası Vira Pandya ise Halaç ordusunun geldiğini haber alınca hazinesini de alarak Birdhûl'den Kandûr'a çekilmişti (Lal, 1950: 207).

Kâfûr, Raca Vira Pandya'yı ele geçirmek için Kandûr'a ilerlemişti. Bu haberi alan Vira Pandya buradan da kaçmıştı. Kâfûr burada biri hazine yüklü 120 fili ele geçirmişti (Kortel, 1994: 105-6). Akabinde altın bir putu ve çok sayıda fili bulunan Brahmapûri'ye ani bir saldırı düzenlemişti. Burada çatısı zümrüt ve yakut taşlarla süslü tapınak yerle bir edilmiş ve yaklaşık 250 fil ele geçirilmişti. Melik Kâfûr Vira Pandya'yı yakalamak için Kum şehrine gitmişti. Buradan da Mâ‘ber'in merkezi Madura'ya varmıştı. Madura ele geçirilerek buradaki Cagannâth Tapınağı yıkılmıştı. Melik Kâfûr Mâ‘ber'in yönetimine Vira Pandya'nın kardeşi Sundara Pandya'yı getirmişti. Böylece Mâ‘ber seferinin askeri kanadı sona ermişti (Kortel, 1994: 106).

Melik Kâfûr fetihnameyi Sultan Alâeddin'e göndermişti. Ardından ele geçirdiği hazine ve fillerle muzaffer bir şekilde Delhi'ye dönmek için harekete geçmişti (Berenî, 2015: 204). Berenî ele geçirilen ganimetleri 612 fil, 96 bin men altın, 20 bin at ve birçok mücevher dolu sandık şeklinde vermektedir (Berenî, 2015: 204; Kulke, 2001: 247). Dihlevî' den aktaran Saksena'ya göre de 512 fil, 500 at ve 500 men ağırlığında çeşitli mücevherlerin ele geçirildiğini belirtmektedir (Saksena, 1970: 417). Nizâmeddin Ahmet ve Firişte ise 312 fil, 20 bin at, 96 bin 


\section{Halaç Sarayında Bir Köle: Melik Kâfûr Hezârdînârî}

men altın ve mücevherlerle dolu birkaç sandık ile değerli taşların ele geçirildiğini belirtmektedirler (Nizâmeddin Ahmed, 1927: 184; Firişte, 1829: 214).

Halaç ordusu 24 Nisan 1311 tarihinde Madura'dan hareket ederek 18 Ekim 1311 tarihinde Delhi'ye varmıştı. Sultan Alâeddin Muhammed Şah Siri'de bulunan Hezâr Sütün sarayının önünde büyük bir karşılama töreni düzenleyerek Güney Hindistan fethine katılan emir ve meliklere derecelerine göre 4 men, 2 men, 1 men ve yarım men ağırlığında altın hediye etmişti (Berenî, 2015: 204; Lal, 1950: 213; Kortel, 1998: 777). Berenî, Delhi'deki yaşlı insanların Dravasamudra ve Mâ‘ber seferlerinde ele geçirilen fil ve mücevherlerin Delhi tarihi boyunca böyle bir ganimete sahip olunmadığından bahsettiklerini ifade etmektedir. Ayrıca bu tarihe kadar hiçbir tarihçi kitabında böyle büyük bir ganimetin Delhi'ye getirildiğine dair bilgi vermediğini de belirtmektedir (Berenî, 2015: 204).

\subsection{Deogir Seferi}

Deogir racas1 1312 yılında vefat etmişti. Raca bu tarihe kadar Sultan Alâeddin Muhammed Şah'a bağlı kalmıştı. Onun ölümü üzerine kardeşi Singhana Deva yönetimi devralmıştı. Raca Singhana başa geçince Sultan Alâeddin'in matbuluğunu tanımamış ve bağımsız hareket etmişti (Lal, 1950: 214; Konukçu, 1977: 185; Prasad, 1963: 159-60). Berenî’ye göre Deogir seferinin diğer sebebi de Telingana racası Rudra Deva'nın Dehi'ye bir mektup ile 20 fil göndermişti. Mektupta yıllık vergisini vermek için Deogir'de hazır beklediğini belirtmişti. Ayrıca vergiyi almak için sultanın birini görevlendirmesini talep etmişti (Berenî, 2015: 204).

$\mathrm{Bu}$ meselenin halledilmesi için Melik Kâfûr Hezârdînârî vazifelendirilmişti. Ancak melik buna pek sıcak bakmamıştı. Ancak Alâeddin'in eşi Melike-i Cihân ve kardeşi Alp Han Kâfûr'u merkezden uzaklaştırma gayreti içerisindeydiler. Zira Kâfûr çıktığı her seferden muzaffer bir şekilde Delhi'ye döndüğü için sultan nezdinde büyük öneme sahipti. Bundan dolayı sultan, Kâfûr'un adamlarına görev vermekte ve onun etkisi altına girmekteydi. Bu durumu ortadan kaldırmak için sultana Kâfûr'u Deogir meselesiyle vazifelendirilmesi için baskı yapmışlardı. Sultan baskı ve israrlara daha fazla karşı koyamayarak onu Deogir meselesi için tekrardan vazifelendirmişti (Konukçu, 1977: 185-6; Lal, 1950: 215).

Yaşanan bu gelişmeler üzerine Melik Kâfûr hem Telingana racasının yıllık vergisini almak hem de Singhana Deva'yı ortadan kaldırmak için Delhi'den yola çıkmıştı. Deogir'e gelen bütün yolları tuttuktan sonra şehri kuşatmıştı. Kâfûr karşısında fazla mukavemet gösteremeyen Raca Singhana Deva öldürülmüştü. Böylece Deogir yeniden Halaç hâkimiyeti altına girmişti. Buranın yönetimine Ram Chandra Deva'nın damadı Harpal Deva'yı tayin etmişti. Melik Kâfûr meseleyi hallettikten sonra Delhi'ye geri dönmüştü (Lal, 1950: 215; Haig, 1928:118).

\section{Melik Kâfûr'un Yönetimi Ele Geçirme Girişimi}

Melike-i Cihân ve kardeşi Gücerat valisi Alp Han sarayda Kâfûr'un gücünü kırmak için onu Deogir seferine göndermişlerdi. Akabinde saray ve sultanın nezdinde konumlarını güçlendirmek için Şehzade Hızır Han'1 Alp Han'ın 
kızı Mahru'yla evlendirmek istemişlerdi. Ancak Hızır Han bu evliliğe sıcak bakmayınca Şehzade Şadi Han ile evlendirilmişti. Melik Kâfûr seferden dönünce aleyhinde gerçekleştirilen oyunları anlamış ve intikam almak için zaman kollamıştı (Konukçu, 1977: 189; Lal, 1950: 297-8).

Melik Kâfûr emellerine ulaşmak için önündeki en büyük engellerden biri olan Alp Han'ı ortadan kaldırmak istemişti. Bu doğrultuda bir gün Alp Han'ı sözde Sultan Alâeddin'in davet ettiği gerekçesiyle saraya çağırmıştı. Sultanın daveti üzerine saraya gelen Alp Han, Melik Kâfûr ve adamı Kemaleddin Gurg tarafindan ele geçirilerek idam edilmişti (Lal, 1950: 300-1; Sirhindi, 1932: 79). Melik Kâfûr, Hızır Han'ı Galyur Kalesi'ne Melike-i Cihân'ı da Köşk-ü Lâl'e sürgün ettirmişti (Berenî, 2015: 227).

Bütün bu hadiseler cereyan ederken Sultan Alâeddin yakalandığı hastalıkla mücadele etmekteydi. Bu durumdan istifade eden Melik Kâfûr, sultanı tamamıla etkisi altına almıştı. Günden güne hastalığı artan Alâeddin 4 Ocak $^{5} 1316$ (7 Şevval 715) tarihinde ebedi hayata intikal etmişti (Sirhindi, 1932: 81; Haig, 1928: 119; Srivastava, 1966:117). Sultan Alâeddin'in naş1 Köşk-ü Siri'den getirilerek sessiz sedasız Cuma Mescidi'nin yanındaki türbesine defnedilmişti (Berenî, 2015: 228; Saksena, 1970: 425).

\subsection{Melik Kâfûr'un Şehzade Ömer Han'ı Tahta Çıkarması ve Yaşanan Olaylar}

Melik Kâfûr Hezârdînârî, Sultan Alâeddin'in vefatından iki gün sonra $6^{6}$ yaşındaki Şehzade Ömer'i "Şihâbeddin" unvanıyla Halaç tahtına çıkarmıştı (Nizâmeddin Ahmed, 1927:190; Berenî, 2015: 229). Akabinde melik, emir ve devletin ileri gelen ricalini saraya davet etmişti. Şehzade Ömer'in tahtın varisi olduğunu teyit ettirmek için sultanın hastalığı sırasında aldığı Ahidname'yi onlara göstermişti. Kâfûr bu yolla Ömer'in saltanatını meşrulaştırmak istemişti (Berenî, 2015: 229; Nizâmeddin Ahmed, 1927: 190).

Melik Kâfûr Hezârdînârî emellerine ulaşmak için önce çocuk yaştaki şehzadeyi tahta çıkarmış ve akabinde de ona varislik yapmak için annesi Melike-i Cihan ile evlenmişti (Lal, 1950: 319; Konukçu, 1977: 198). Böylece Kâfûr, Halaç hâkimiyetini tamamen kontrolüne almıştı. Ancak Hızır Han ve Şadi Han'ın hayatta olmaları onun için büyük engel teşkil etmekteydi. Bundan dolayı Melik Kâfûr kendisine oluşabilecek mukavemeti ortadan kaldırma çabası içerisine girmişti. Galyur Kalesi'nde tutsak ettiği Hızır ve Şadi Han'ın gözlerine mil çektirmek için Sambal adında birini vazifelendirmişti. Sambal, Galyur Kalesi'ne giderek Hızır ve Şadi Han'ın gözlerine mil çekmişti. Akabinde hapsedilmiş olan Hızır Han'ın

\footnotetext{
${ }^{5}$ Alâeddin Muhammed Şah'ın ölüm tarihi çoğunlukla kaynaklarda 7 Şevval 715 geçmektedir. Ancak hicri takvimi miladi takvime çevirirken gün farkı oluştuğu görülmektedir. Örneğin Târih-i Mubârekşahi İngilizceye çeviren Basu 9 Ocak tarihini belirtirken Lal ve Konukçu 6 Ocak tarihini vermektedir. Bu çalışmada hicri takvimi miladi takvime çevirmede Türk Tarih Kurumu'nun Tarih Çevirme programı kullanılmıştır. Bundan dolayı 4 Ocak tarihi verilmiştir.

${ }^{6}$ Firişte Şehzade Ömer' in yaşını 7 olarak vermektedir (Firişte, 1829: 219).
} 


\section{Halaç Sarayında Bir Köle: Melik Kâfûr Hezârdînârî}

annesi Melike-i Cihan'ın bütün mallarına el konulmuştu (Firişte, 1829: 219; Nizâmeddin Ahmed, 1927: 190; Berenî, 2015: 230).

Melik Kâfûr, Sultan Alâeddin Muhammed Halaci'nin diğer çocukları Ferid, Osman, Muhammed ve Ebubekir Han'a da çeşitli işkenceler yaparak onlarında gözlerine mil çektirmişti. Kâfûr'un hezimetinden sadece Şehzade Mubarek Han kurtulabilmişti (Nizâmeddin Ahmed, 1927: 190; Berenî, 2015: 230; Firişte, 1829: 219). Kâfûr, Mubarek Han'ın gözlerine mil çektirmek için Peyk adında bir adamını görevlendirmişti. Peyk, şehzadenin gözlerine mil çekmek için gittiğinde Mubarek Han boynundan altın kolyesini çıkararak bağışlanması karşıllğında ona vermişti. Peyk kolyeyi alarak Mubarek Han'ın hayatını bağışlamıştı (Berenî, 2015: 232; Firişte, 1829: 220).Bu durumdan habersiz olan kâfûr bir sultan edasiyla hareket etmekte ve eyaletlere, racalara emirnameler göndermekteydi (Konukçu, 1977: 200) .

\section{Melik Kâfûr Hezârdînârî’nin Öldürülmesi}

Saray ahalisinden bazı önemli kimseler Mubarek Han'ın gözlerinin kör edilmediğini ve sağ olduğunu haber almışlardı. Bunun üzerine Kâfûr'u ortadan kaldırmak ve Şehzade Mubarek Han'ı tahta çıkarmak için harekete geçmişlerdi. Ayrıca Mubarek Han'ı katletmeyen Peykler şehzadenin etkisinde kalarak Kâfûr'u ortadan kaldırmak için firsat kollamaktaydılar. Bu doğrultuda Mubaşir, Beşir, Salih ve Münir adlı dört peyk Kâfûr'u katletmek için hazırlık yapmışlardı (Lal, 1950: 321; Sirhindi, 1932: 81). Nihayetinde bir gece Kâfûr'un odasına giren peykler onu hançerleyerek öldürmüşlerdi (Berenî, 2015:232; Sirhindi, 1932: 81; Firişte, 1829: 220). İbn Battuta hadiseyi şu şekilde aktarmaktadır:

"Sultan Alâeddin'in seçkin bendelerinden Beşir ve Mübeşşir diye bilinen iki adam, Alâeddin'in eşi Muizziddin'in kızı olan büyük hatun tarafindan çağrıldl. Baş hatun bu iki köleyi karşısına çekip onlara efendilerinin iyiliklerini hatırlattı ve ekledi: "Şu genç Melik Naib, evlatlarıma ne yaptı biliyor musunuz? O, Kudbeddin'i de öldürmek istiyor" iki adam: "Ne yapacağımızı göreceksin! diye cevap verdiler. Zaten Melik Naib'in yanında gece nöbeti tutmak hatta onun huzuruna silah ile girmek bu kölelerin her zamanki işiydi. O gece Naib oralıların "hurramka" (Hürremgâh: sevinç yeri) adını verdiği, kumaş kapl ahşap bir odadayken Beşir ve mübeşşir geldi. Melik Naib yağmur mevsiminde sarayın daminda kurulan bu odada uyurdu. Rastlantiya bakın ki hizmetkârlarından birinin elinden kilıcını alıp oynadıktan sonra geri vermişti. Köle birden kllicu indirdi Naib'in üstüne. Arkadaşı da ikinci darbeyi indirdi. Seçkin bendeler, adamın başını gövdesinden ayırarak Kudbeddin'in hapsedildiği hücreye götürdüler, önüne attılar ve onu zindandan çıkardılar" (İbn Battûta, 2000: 633-4).

Böylece Melik Kâfûr hezârdînârî’nin 35 günlük süren Halaç hâkimiyeti 11 Şubat 1316 tarihinde son bulmuştu (Nizâmeddin Ahmed, 1927: 190; Firişte, 1829: 219; Lal, 1950: 322). Şehzade Mubarek Han bir süre Sultan Şihâbeddin'in 
nâ‘ibliğini yapmıştı. Akabinde Şihâbeddin'i tahtan indirerek 14 Nisan 1316 tarihinde Kudbeddin Mubarek Şah adıyla Halaç tahtına oturmuştu (Berenî, 2015: 232; sihrindi, 1932: 81-2; Nizâmeddin Ahmed, 1927: 191-2).

\section{Kâfûr Hezârdînârî’nin Türbesi}

Günümüzde Melik Kâfûr'un mezarının nerede olduğu tam olarak bilinmemektedir. Ancak onun 11 Şubat 1316 tarihinde ölümü üzerine Delhi' de defnedildiği muhakkaktır. Halaçların hâkimiyetine son vererek Hindistan'da devlet kuran Tuğlukşahlar Devleti'nin üçüncü sultanı Firuz Şah saltanatı döneminde Delhi ve çevresindeki birçok mimari yapıyı restore etmişti. Sultanın restore ettiği yapılardan biri de Melik Kâfûr Hezârdînârî'nin türbesiydi. Melik Kâfûr'un türbesi bakımsızlıktan yıkılma noktasına gelmişti. Sultan Firuz Şah, Kâfûr'un Sultan Alâeddin'in önemli komutanlarından olduğunu ve daha önce hiçbir sultan döneminde Türk atlarının ayak basmadığı toprakları fethederek onun adına hutbe okuttuğunu bilmekteydi. Bundan dolayı Melik Kâfûr'un türbesini tamir ettirmişti (Sultan Firuz Şah, 1871: 384). Ayrıca Enver Konukçu "Hindistan'daki Kalaçların Başkentleri:Lakhnauti, Delhi, Dhar ve Mândû" adlı makalesinde Delhi'deki mimari eserleri verirken Melik Kâfûr'un türbesinden de bahsetmektedir (Konukçu, 2008: 156).

\section{Sonuç}

Melik Kâfûr Kambay seferi sırasında Nusret Han tarafından bin dinara satın alınarak saraya getirilmişti. Genç yaştaki hadım köle kısa sürede Sultan Alâeddin'in güvenini kazanmış ve ordu komutanı mevkiine ulaşmıştı. Kâfûr askeri ricalden gelmemesine rağmen çıktığı seferlerden başarılı bir komutan olarak dönmeyi başarmıştı. Onun Dravasamudra ve Mâ‘ber üzerine yaptığı seferler sonucunda Halaçlar Güney Hindistan toprakları üzerinde hâkimiyet tesis etmişlerdi. Ayrıca İslamiyet'in bu bölgede yayılmasına da önemli katkı sağlamıştı. Melik Kâfûr'un başarısı arttıkça sultan nezdinde güveni ve itibarı da artmıştı. Öyle ki Sultan Alâeddin sefer dönüşlerinde onu resmi törenle karşılamıştı.

Melik Kâfûr konumunu güçlendirdikten sonra bu durumu kendi emelleri doğrultusunda kullanmaya başlamıştı. Bunun oluşmasında Kâfûr'un başarısını kıskanan Melike-i Cihân ve Kardeşi Alp Han'ın da etkisi olmuştu. Ayrıca sultanın yaşının ilerlemesi ve hastalığının da artması bir diğer etken olmuştu. Nihayetinde Melik Kâfûr, Sultan Alâeddin'in ölümü üzerine çocuk yaştaki Şehzade Ömer'i tahta çıkarmıştı. Akabinde de şehzadenin annesi Melike-i Cihân ile evlenerek Halaç tahtının varisi olmuştu. Böylece köle olarak geldiği Halaç sarayının tahtına sultan olarak oturmuştu.

Melik Kâfûr yönetimi ele geçirdikten sonra kendisine mukavemet gösterecek kişileri ortadan kaldırmak istemişti. Bu doğrultuda Şehzade Hızır, Şadi, Ferid, Osman, Muhammed ve Ebubekir'in gözlerine mil çektirerek hapse attırmıştı. Kâfûr'un zulmünden Şehzade Mubarek Han kurtulabilmişti. Yaptığı zulme daha fazla kayıtsı kalamayan peykler düzenledikleri suikastla onu ortadan kaldırmışlardı. Böylece Güceratlı bir kölenin Halaç Sarayı'na ve saltanatına uzanan 


\section{Halaç Sarayında Bir Köle: Melik Kâfûr Hezârdînârî}

serüveni son bulmuştu. Kâfûr'un bu emelleri onu ölüme götürdüğü gibi döneme damgasını vurmuş Halaç Sultanlığı'nı da çöküşe götürmüştü.

\section{Kaynakça}

Bayur, Y. Hikmet. (1946). Hindistan Tarihi, cilt I, Ankara: Türk Tarih Kurumu Basımevi.

Cöhce, Salim. (2008). "Kalaç Sultanlı̆̆ı", Tarihte Türk-Hint İlişkileri Sempozyumu Bildirileri, 25-28 Haziran 2007, say1 12,Ankara,s.77-89. ,(2002). "Hindistan'da Kurulan Türk Devleri", Türkler Ansiklopedisi, cilt

VII, Ankara,s.689-742.

Digby, Simon. (1978). "Kâfûr", $E l^{2}$ vol IV, Leiden,s.419.

Dihlevî, Emir Hüsrev. (1970). "Târîh-i Alâ̂”, (İng. çev. H. M. Elliot)A Comprehensive History of India, vol V, Delhi.

Haig, Sir Wolseley. ( 1928). The Cambridge History of India Turks and Afghans, vol. III, Cambridge at the University Press, London.

Halaçoğlu, Yusuf. (1989). "Alâeddin Halacî", DİA., cilt II, İstanbul,s.330.

İbn Battûta Tancî. (2000). İbn Battûta Seyahatnâmesi, (çev. ve not. A. Sait Aykut), cilt II, İstanbul, Yap1 Kredi Yayınları.

Kafesoğlu, İbrahim. (1976 ). "Delhi Türk Sultanlığı (1206-1413), Türk Dünyası El Kitabl, Ankara, s.323.

Konukçu, Enver. (1976 ). "Kalaç Sultanı Alâeddin Muhammed Şâh ve Onun Hind Siyâseti”, VIII. Türk Tarih Kongresi, cilt II, 11-15 Ekim, Ankara, s.793798.

( 1987 ). "Hindistan'da Kurulan Türk Devletleri (1206-1414)", Tarihte Türk Devletleri, cilt I, Ankara Üni. Basımevi, Ankara,s.347-358.

(1977). Kalaç Sultanlığı(1290-1320) "Delhi'de Türklerin İkinci Hakimiyet Devresi”, (Doçentlik Tezi), Atatürk Üniversitesi Edebiyat Fakültesi, Erzurum.

,( 2008 ). "Hindistan'daki Kalaçların Başkentleri:Lakhnauti, Delhi, Dhar ve Mândû", Tarihte Türk-Hint İlişkileri Sempozyumu Bildirileri, 25-28 Haziran 20007, Ankara,s.145-171.

KORTEL, S. Halûk. (1998). "Delhi Türk Sultanı Alâeddîn Muhammed Şâh Halacî'nin Hindistan'daki seferleri" Belleten, cilt LXII, S. 235 Aralık, Ankara,s.747-786.

( 1994). Delhi Sultanlarından Halacîler (Alâeddin Muhammed Şâh Halaci Devri), (Yayımlanmamış Y.L.T.) İstanbul Üni., İstanbul.

,(2015 ). "Delhi Türk Sultanlarının Telingana Seferleri”, Avrasya İncelemeleri Dergisi IV/I, İstanbul, s. 1-26.

Köprülü, Orhan Fuad. (1996). "Fîrûz Şah Halacî”, DİA.,cilt XIII, İstanbul, s.140141.

Köprülü, Fuad. (1978). “Alâeddin Halacî”, $\dot{I} A$., cilt I, İstanbul, s.279-282.

Kulke, Hermann ; Rorhermund, Dietmar. ((2001). Hindistan Tarihi, (çev. Müfit Günay), Ankara, İmge Kitabevi.

Lal, K.S. (1950). History of the Khaljis1290-1320, Allahabad, The İndian Press. 
Merçil, Erdoğan. (2006). Müslüman-Türk Devletleri Tarihi, 5. baskı Ankara, Türk Tarih Kurumu Basımevi.

Muhammed Kasım Hinduşah Firişte. (1829). Tarîh-i Firişse, (İng trc. John Briggs), History of Muhammadan Powar of İndia, London.

Nizâmeddin Ahmed. (1927).Tabakat-ı Ekberî, (İng. çev., B. De), Calcutta.

Prasad, İshwari. (v). A New History of İndia, Allahabad.

Saksena, Banarsi Prasad. (1970 ). "Alauddin Khalji”, A Comprehensive History of India in Twelve Volumes ; The Delhi Sultanat, vol. V, People's Publishing House, New Delhi.

Sastri, K.A. Nilakanta. (1942). The Early Muslim Expansion in South Indai, University of Madras.

Singh, Sukhdev. (2005). The Muslims of Indian Origin During The Delhi Sultanate Emergence, Attitudes and Role, New Delhi.

Srivastava, Ashirbadi Lal. (1966). The Sultanate of Delhi (711-1526 A.D.) The Educational Press, Agra.

Sultan Firuz Şah. (1871). Fütûhât-ı Firuz Şahî, (İng çev. Sir H. M. Elliot), The History of İndia, As Told by İts Own Historians, vol III, London.

Yahya bin Ahmed bin Abdullah Sirhindi. (1932.).Târîh-ı Mubârakşâhi, (İng. çev.K.K. Basu), Oriental İnstitute, Baroda.

Ziyâeddîn Berenî. (2015).Târîh-i Fîrûzşâhî, (İng çev. İshtiyaq Ahmad Zilli), Primus Books, Delhi.

https://commons.wikimedia.org/wiki/File:The_last_act_of_Malik_Naib_Kafur,_A. D._1316.jpg(20/01/2021) 


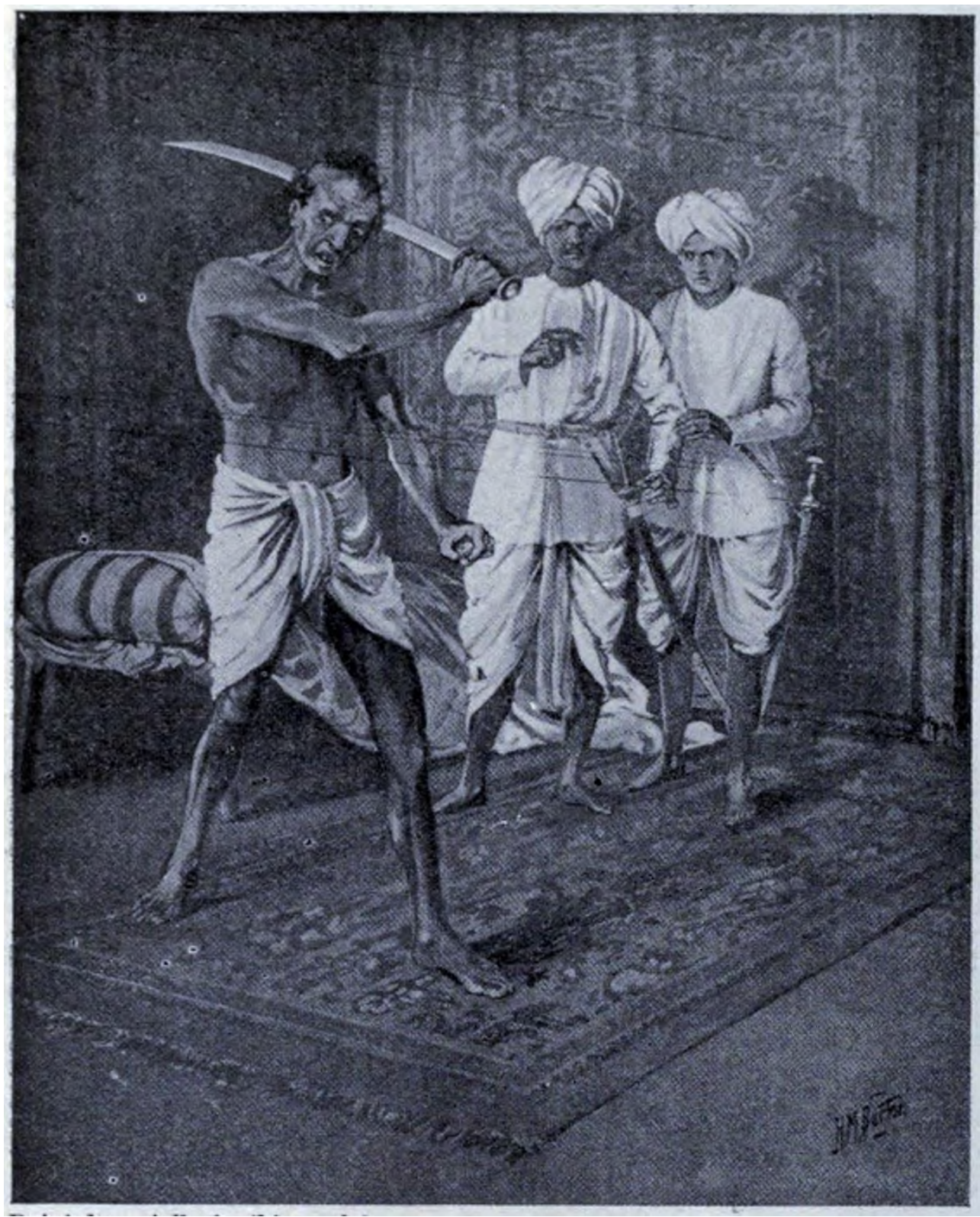

Kaynak:https://commons.wikimedia.org/wiki/File:The_last_act_of_Malik_Naib_ Kafur,_A.D._1316.jpg(20/01/2021)

Resim: 1 Melik Kâfûr'un Katledilişini Gösteren Resim. 